The Developing Common Market 
By the same author

THE STATESMAN'S YEAR-BOOK (editor)

EVERYMAN'S DICTIONARY OF ABBREVIATIONS

WORLD LEGISLATURES

THE STATESMAN'S YEAR-BOOK WORLD GAZETTEER

EUROPEAN POLITICAL FACTS 1815-1918 (with Chris Cook)

EUROPEAN POLITICAL FACTS 1918-1973 (with Chris Cook)

SMUGGLING (with John Wroughton)

TRADE IN THE COMMON MARKET COUNTRIES (with Arthur Walsh)

TRADE AND INDUSTRIAL RESOURCES OF THE COMMON MARKET AND EFTA COUNTRIES (with Arthur Walsh)

COMPETITION POLICY (with Arthur Walsh) 


\section{The Developing Common Market}

\section{John Paxton}

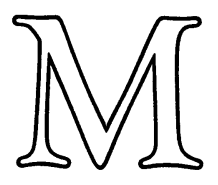


(C) John Paxton and A. E. Walsh 1968, 1972 (C) John Paxton and Mrs L. Walsh 1976

Softcover reprint of the hardcover 1st edition 1976 978-0-333-19018-0

All rights reserved. No part of this publication may be reproduced or transmitted, in any form or by any means, without permission

First edition under the title The Structure and Development of the Common Market 1968 Second edition under the title Into Europe 1972 (both published by Hutchinson) Third edition (completely revised) first published 1976 by THE MACMILLAN PRESS LTD London and Basingstoke Associated companies in New York Dublin Melbourne Johannesburg and Madras

SBN 333190181

This book is sold subject to the standard conditions of the Net Book Agreement 
TO THE MEMORY OF

ARTHUR WALSH

18 January 1895-14 October 1974

an energetic student of European business studies 


\section{Contents}

Acknowledgements viii

Preface $\quad$ ix

1 Post-War Europe 1

2 The Terms of Britain's Entry into the E.E.C. 21

3 The Treaties of Rome and Brussels 29

4 The Institutions of the European Communities 52

5 The Tariff Structure $\quad 60$

6 Community Law in the Member-States 71

7 The Social and Development Funds and Investment Bank 76

8 Agriculture and Fisheries $\quad 81$

9 Sales and Turnover Taxation $\quad 109$

10 The Rules of Competition $\quad 121$

11 Industrial Property: Patents and Trade Marks 132

12 Social Security 138

13 Mobility of People and Capital 145

14 Trade Unions 152

15 A Common Transport Policy 156

16 The European Coal and Steel Community and Euratom 161

17 Regional Policy 193

18 Agreements of Association and Trade 202

$\begin{array}{ll}\text { Statistical Appendix } & 226\end{array}$

Some Suggestions for Further Reading 230

$\begin{array}{ll}\text { Index } & 233\end{array}$ 


\section{Acknowledgements}

Over many years I have received help from officials of the Commission of the European Communities in Brussels and London. I am particularly grateful to Richard Mayne in London and Jack Peel in Brussels.

I should also like to thank Dr. Walter Rosenberger of Keesing's Contemporary Archives, and again my gratitude goes to the indexer, Mrs. D. Fetherstonhaugh, and to Mrs. P. White for excellent typing. But above all I am extremely grateful for the hard work undertaken in the pre-planning stage of this book by Arthur Walsh before his death in the autumn of 1974. 


\section{Preface}

The Treaty of Rome is one of the most remarkable documents in the social and economic history of the western world. It is explicit in providing for complete economic union so that goods, people and capital will be able to pass over the national boundaries of the member countries as freely as they can move inside any one country today. No past attempt at federation, whether successful or not, can be compared with the magnitude of the task formally begun in 1957.

Of the millions of words written and spoken about the European Economic Community since the signing of the Treaty of Rome the majority concerned international and European trade. Indeed the expression 'Common Market' was unfortunate in that the general public could well have believed that the E.E.C. was just another customs union. In recent years much more concern and action has been taken on human and social problems of the E.E.C. and it is in these areas where important decision making will take place in the next five years.

On the horizon lies political union.

JOHN PAXTON

Bruton, Somerset

Summer 1975 